\title{
Current trends in leather science
}

\author{
Anthony D. Covington * ${ }^{*}$ and William R. Wise
}

\begin{abstract}
In preparing the second edition of 'Tanning Chemistry. The Science of Leather.', the literature was updated and the content was revised and reviewed. Here, the new findings are presented and discussed.

Notable developments include the necessary rethinking of the mechanism of sulfide unhairing because of new understanding of the aqueous chemistry of sulfide species. Revision upwards of the value of the second pKa for sulfide species ionisation means that $\mathrm{S}^{2-}$ cannot exist in an aqueous medium, so the unhairing species in hair burn reactions is $\mathrm{HS}^{-}$. Although the technology remains the same, this means the mechanisms of associated reactions such as immunisation must be revised.

Rawstock preservation has benefitted from studies of the potential role of materials from plants which accumulate salt, but which also contribute terpene compounds. There is also further discussion on the continuing issue of chromium (VI) in the leather industry.

The application to processing of new solvents, ionic liquids and deep eutectics, is the coming technology, which offers transforming options for new chemistries and products. Renewed interest in vegetable tanning and methods of wet white processing are current trends. Also, within the topic of reagent delivery is processing in a solid medium of plastic beads.
\end{abstract}

\section{Introduction}

This review sets out the more notable contributions to the leather literature over the last decade. Two observations are clear.

(i) The distribution of new knowledge over the range of topics within the subjects of leather technology and leather science is not even. Less work has been done on the beamhouse compared with tanning and post tanning.

(ii) The sources of research results have narrowed: Chinese papers dominate the content of JSLTC, Indian papers dominate the content of JALCA. In both cases, papers are noticeably shorter in recent years.

The new work judged to be of value is presented in the updated second edition of the Royal Society of

\footnotetext{
* Correspondence: tonycovington@btinternet.com; tony.covington@northampton.ac.uk

Institute for Creative Leather Technologies, University of Northampton, University Drive, Northampton NN1 5PH, UK
}

Chemistry's publication 'Tanning Chemistry. The Science of Leather' [1]. The developments are set into context and the relevance discussed.

\section{Preservation}

Preservation of rawstock remains the main problem for the global leather industry because of the primary problem of salt and its disposal. Many additives have been used in industry, but none has had the function of decreasing the amount needed for the required period of preservation. A new approach is to use halophyte plant material: one such is Sesuvium portulacastrum leaf, containing $18 \%$ sodium and $15 \%$ chloride on dry weight. It was noted that the treatment was biocidal (unlike salt, which is bacteriostatic), attributed to the terpene content of the leaf [2]. Other leaf materials have shown useful effects: Clerodendrum viscosum [3] and Tamarindus indica [4] alone or in combination with salt are effective preserving agents. For the developing economies, testing indigenous plant species might prove beneficial.

Trials of polyethylene glycol suggest that lower molecular weight species can be effective $[5,6]$. Short term

\section{Springer Open}

(c) The Author(s). 2020 Open Access This article is licensed under a Creative Commons Attribution 4.0 International License, which permits use, sharing, adaptation, distribution and reproduction in any medium or format, as long as you give appropriate credit to the original author(s) and the source, provide a link to the Creative Commons licence, and indicate if changes were made. The images or other third party material in this article are included in the article's Creative Commons licence, unless indicated otherwise in a credit line to the material. If material is not included in the article's Creative Commons licence and your intended use is not permitted by statutory regulation or exceeds the permitted use, you will need to obtain permission directly from the copyright holder. To view a copy of this licence, visit http://creativecommons.org/licenses/by/4.0/. 
preservation can be achieved with a mixture of acetic and benzoic acids [7]. With regard to short term preservation by chilling, Chandra Babu et al. have shown that the impact of low temperature on bacillus species is not uniform, indicating that some biocide may be required in this technology to make it completely effective [8].

Any rawstock preservation treatment must be economic, have minimum environmental impact and be available. Developed economies are better placed to take advantage of new technologies, but it must be a priority to find suitable applications for the developing economies.

\section{Unhairing}

The use of sodium sulfide for unhairing has been accepted as part of the technology of unhairing for two centuries and there is an associated mechanism which has hitherto not been questioned. However, the 'Rubber Book' has recently revised the dissociation constant for hydrosulfide upwards, from the previously accepted value of 13 to 19 (pKa2) [9].

$$
\begin{array}{ll}
\mathrm{H}_{2} \mathrm{~S} \leftrightharpoons \mathrm{HS}^{-}+\mathrm{H}^{+} & \mathrm{pKa} 1 \\
\mathrm{HS}^{-} \leftrightharpoons \mathrm{S}^{--}+\mathrm{H}^{+} & \mathrm{pKa} 2
\end{array}
$$

The first pKa is unchanged, at about 6, but Raman spectroscopy studies could not detect the sulfide ion even at very high $\mathrm{pH}$ and therefore conclude that the sulfide ion does not exist in aqueous media [10]. This does not change the technology of lime/sulfide unhairing, but it does change the mechanism and the rate equation which must now include a term for the hydroxyl ion, since the $\mathrm{S}^{2-}$ species in the mechanism should be replaced by $\mathrm{HS}^{-}$with $\mathrm{OH}^{-}$[11].

Alternative unhairing systems continue to be sought and Valeika et al. have proposed using sodium metasilicate as an immunising agent prior to sulfide (hydrosulfide/hydroxyl) attack in a hair saving process $[12,13]$. The ideal enzymatic unhairing process has still not been found, but in a serine protease reaction, EDTA has been proposed to sequester the metal ion of the collagenase component and render the remaining proteolytic reaction less damaging to pelt structure [14].

Unhairing will always be a part of leather processing and hair saving is likely to become the industry norm. New approaches to the chemistry are welcome, but the new thinking which must now be applied to the mechanism of keratin degradation is useful for refocusing attention on how the outcome may best be achieved.

\section{Liming}

Rabinovich continues to propound the view that an important aspect of the opening up process is the lyotropic influence of ions according to the Hofmeister series [15].
He undoubtedly has a point and the application to technology requires a serious scientific study.

The introduction of ionic liquids into leather technology is an important development for the future, see below. Indian workers have taken the first steps by introducing an IL as a reagent (rather than a solvent) in unhairing/liming [16]. The effect on opening up was thought to be responsible for enhanced chrome uptake, but the impact of the IL in dilute aqueous medium is not yet established.

With the concept of hair save unhairing becoming mainstream technology, Daniels et al. have demonstrated the practicality of lime liquor recycling, as part of an approach to closed loop operations [17].

The opening up step in the beamhouse, the 'liming', is a fundamentally important process in defining the properties and performance of the final leather. Little work has been done on developing new technologies in the last decade. Two aspects are ripe for research: the inorganic chemistry and the biochemistry of collagen modification.

\section{Chrome tanning}

Little has changed in chrome tanning science in the last decade. It was recognised decades earlier that the way forward to make step changes in understanding would be through molecular modelling. Chinese workers have modelled complexation and concluded that reaction at aspartate is faster, but glutarate is more stable [18]. Interestingly, they found that sulfate plays no part in the outcome of carboxylate complexation, in line with current theory on the tanning reaction, see below.

Attention remains focused on the role of hexavalent chromium in chrome tanned leather. Moretto concludes that, because few people are sensitised to chromium, abreaction to leather is a minor problem so long as tanners use chromium (III) properly [19]. Tegtmeyer and Kleban reviewed the rules for avoiding $\mathrm{Cr}$ (VI) in leather, concluding content can be estimated to be in the range 0.005-0.05 ppm [20]. The mechanism by which chromium (III) is converted to chromium (VI) uses free radicals and can therefore be stopped by free radical scavengers, such as benzoic acid [21]. Plant polyphenols are also effective, best exemplified by tara, a hydrolysable tannin; condensed tannins are less effective [22]. Storage conditions at high temperature can drive the oxidation reaction, when it would be necessary to incorporate in inhibitor into the formulation [23].

The global industry is still on the defensive regarding the role of chromium (VI) in chrome tanned leather. Some of the latest publications are useful in countering the attacks, which are rarely based on sound science and a recent study by Wise et al. has cast doubt on the methods used to measure low concentrations of the offending species $[24,25]$. 


\section{Mineral tanning}

Technologists continue to pursue mineral tanning options, addressing complexes of metal salts other than chromium (III) which might serve a useful purpose to industry. Aluminium (III) is still a favoured field, whether complexed/mixed with carboxylate and/or silicate [26] or other metals, where the impact on properties is additive [27, 28].

Iron tanning has been around for about a century, but has serious associated problems, not least the redox effect on detanning over time, whether or not stably complexed with for example gluconate [29].

Zinc (II) tanning is newer. Its toxicity notwithstanding, complexes of a metal at the end of a transition metal row would not be expected to react strongly with collagen. Indeed, studies of masked salts alone and in a mixture with titanium (IV) produce shrinkage temperature around $80^{\circ} \mathrm{C}$, also as expected [30, 31].

Research on inorganic tannages is not useful: the options throughout the periodic table have been reviewed and defined. However, there is still work to be done on the chromium (III) tanning reaction and the wider role of its complex derivatives chemistry.

\section{Vegetable tanning}

Vegetable tanning remains of interest because of the commercial value of non-mineral tanning and the perception of the ecological credentials or organic tanning. The principles are well understood, but there may be additional advantages, since it has been shown that the prodelphinidin Myrica rubra confers resistance to UV attack at tyrosine sites [32].

The reaction between vegetable tannins and collagen conforms to Fick's Second Law, expressed here for one dimension [33]:

$$
\frac{\partial \mathrm{C}}{\partial \mathrm{t}}=\mathrm{D}_{\mathrm{eff}} \frac{\partial^{2} \mathrm{C}}{\partial \mathrm{Z}^{2}}
$$

Where: $\mathrm{C}=$ concentration of tannin free to diffuse, expressed as the amount of tannin per unit volume of hide.

$D_{\text {eff }}=$ effective diffusion coefficient.

$\mathrm{Z}=$ longitudinal coordinate.

It has also been modelled using modified versions of the Cegarra-Puerte equation [34].

$$
\begin{aligned}
& \mathrm{Q}_{\mathrm{e}}=\mathrm{K} \sqrt{\mathrm{t}} \\
& \ln \left[1-\left(\mathrm{Q}_{\mathrm{t}}{ }^{2} / \mathrm{Q}_{\infty}{ }^{2}\right)\right]=-\mathrm{Kt} \\
& \ln \left[-\ln \left(1-\left(\mathrm{Q}_{\mathrm{t}}{ }^{2} / \mathrm{Q}_{\infty}{ }^{2}\right)\right)\right]=\mathrm{alnt}+\mathrm{alnK}
\end{aligned}
$$

Using Eq. 3, kinetic studies allowed rate constants to be measured as a function of temperature, with or without a pre-treatment of the pelt by protease at $\mathrm{pH} 7.2$.
The latter condition causes an acceleration of polyphenol uptake [35]. Ultrasound has been shown to speed up the rate of diffusion of vegetable tannins in pelt and could be the basis for conducting such reactions in drums [36].

The semi metal tanning mechanism is well known, the synergistic combination of hydrolysable polyphenol with metal salts: the reaction is most effective with aluminium (III), but functions well with some transition metals. An unusual version has been reported using laponite clay as the mineral component $[37,38]$.

$\mathrm{Na}_{0.7} \mathrm{Si}_{8} \mathrm{Mg}_{5.5} \mathrm{Li}_{0.3} \mathrm{O}_{20}(\mathrm{OH})_{4}+12 \mathrm{H}^{+}+8 \mathrm{H}_{2} \mathrm{O} \rightarrow 0.7 \mathrm{Na}^{+}+8 \mathrm{Si}(\mathrm{OH})_{4}+5.3 \mathrm{Mg}^{+}+0.4 \mathrm{Li}^{+}$

The clay is thought to decompose according to the equation given above. Since none of the products is a metal species known to be effective in this context, it is not surprising that the shrinkage temperature achieved is below $90^{\circ} \mathrm{C}$.

The research interest in organic tanning and plant polyphenol chemistry in particular opens up the opportunity to apply kinetics, thermodynamics and modern leather science thinking to the traditional process. In this way, the components could be used more specifically, including converting polymeric species to more useful reagents.

\section{Other tannages}

Suparno has reinvestigated chamois tannage using rubber seed oil [39-41]. Compared to fish oil, they have similar iodine values, a measure of unsaturation, so the new reagent functions well in this reaction. The result from the rubber seed oil is less colour and odour: using hydrogen peroxide, the reaction time can be shortened to three days.

Linseed oil is another option, but it creates weaker leather than the conventional fish oil tanned product, with lower water retention [42]. Studies have also been undertaken with oil from Japanese anchovy (Engraulis japonicus), applying it after oxidation rather than in situ. Probably unsurprisingly, they observed no chamoising effect, but still questioned the accepted reaction mechanism [43].

In the field of syntans, lignin has long been considered as a precursor, but with limited commercial success. This can be considered to be the beginning of a trend towards replacing petrochemical polymers with biopolymers as the basis for syntans. Bacardit and co-workers have suggested an analogous source of reagents based on humic acid [44, 45]. In descending order of reactivity they are: lignin, humic acids (extracted from lignite coal at $\mathrm{pH}$ 10-12), huminas (obtained by oxidation of coal, huminas, bitumen) and bitumen. Like lignin, these 


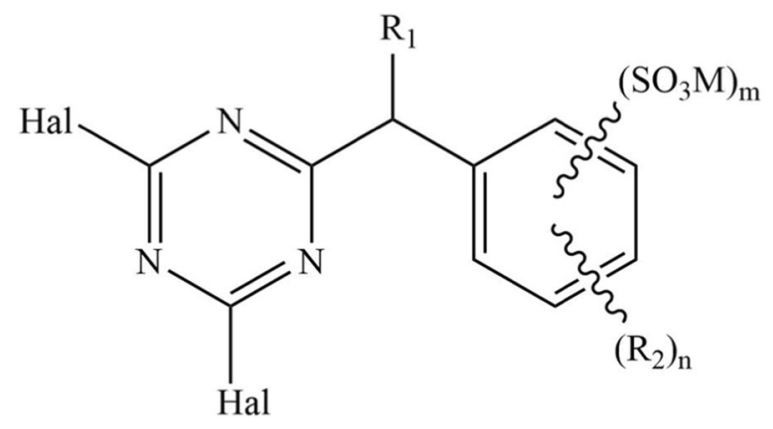

Fig. 1 The basis of Stahl's EasyWhite process

materials can be sulfited and perform similar functions in tanning.

A continuing problem with syntans is formaldehyde in the product. Shi has suggested using glyoxal, $(\mathrm{CHO})_{2}$, as a crosslinker, but this has not been demonstrated to be a commercial option [46].

Polyaldehyde from the oxidation of starch is well known to the industry. Other biopolymer carbohydrates can equally be used as the feedstock, such as dextrin [47] and alginates [48]. It has been suggested that such reagents could be used in combination with other aldehydic compounds: a small degree of synergy was found, but all leathers proved to be weaker than chrome tanned leather.

Aromatic heterocycles are established in reactive dyestuff chemistry and this has been extended into syntan application in Stahl's EasyWhite product [49]. As indicated in Fig. 1, the triazine ring can react covalently with collagens, carrying the rest of the molecule into the protein structure for additional reaction.

Lanxess have industrialised Traubel's development of isocyanate chemistry [50] to create X-tan. Diisocyanate derivatives can function as crosslinking agents.

$$
\begin{array}{ll}
\mathrm{R}-\mathrm{NCO}+\mathrm{NaHSO}_{3} \leftrightharpoons \mathrm{R}-\mathrm{NH}-\mathrm{CO}-\mathrm{SO}_{3}{ }^{-} \mathrm{Na}^{+} \leftrightharpoons \mathrm{R}-\mathrm{NH}-\mathrm{CO}-\text { protein } \\
\text { Isocyanate } & \text { carbamoyl sulfonate }
\end{array}
$$

The volume of useful work on organic tanning processes indicates continuing interest in tannages which do not rely on inorganic reagents. There is great potential in this area, particularly if the requirements for new link-lock synergy and the achieving of high hydrothermal stability are the end goals.

\section{Post tanning}

It is traditional to think of the post tanning period in processing to consist of retanning, dyeing and fatliquoring, each of which might involve a series of steps for multiple reagents. This is not helpful in considering the predictability of the outcome. It is more useful to regard the sequence of additive or fixation reactions as a multiple combination, in which each component interacts with previous and subsequent components according to fixed rules of affinity.

As an example, tanning steps are described as 'pretanning', 'tanning' or 'retanning', as though they are specific functions of particular chemistries. In fact, the terms only refer to the timing of their application and their relative importance is dependent on the way in which the reagents interact on collagen to confer certain properties and performance in the leather.

The consideration of multiple fixation reactions is not confined to conventional tanning agent; analysis must extend to all fixation reactions, including dyeing and fatliquoring, since those mechanisms are included in the range of tanning reactions. From a knowledge of the impact of reagents on the properties and performance of leather, the outcome of processing can be predicted; moreover, from a notion of the required properties of a new leather, the necessary process can be predicted.

\section{Dyeing}

Traditionally, dyes have been designated in the following chemical types: mordant, acid, basic, direct, premetallised, reactive and sulfur. Now another two types can be added to the list. Aryl carbonium-based dyes would appear to be a new class of dyes, exemplified by Malachite Green, as shown in Fig. 2 [51]. However, it is also the basis of the first of the synthetic dyes, mauveine, also shown in Fig. 2.

Fungal sources can yield colourants, as illustrated in Fig. 3 [52]. The examples from Monascus spp. can<smiles>Cc1ccc(Nc2ccc3nc4cc(C)c(C)cc4[n+](-c4ccccc4)c3c2)cc1</smiles><smiles>CN(C)c1ccc(C(=C2C=CC(=[N+](C)C)C=C2)c2ccccc2)cc1</smiles>

Fig. 2 The structures of mauveine and Malachite Green (Cl Basic Green) 

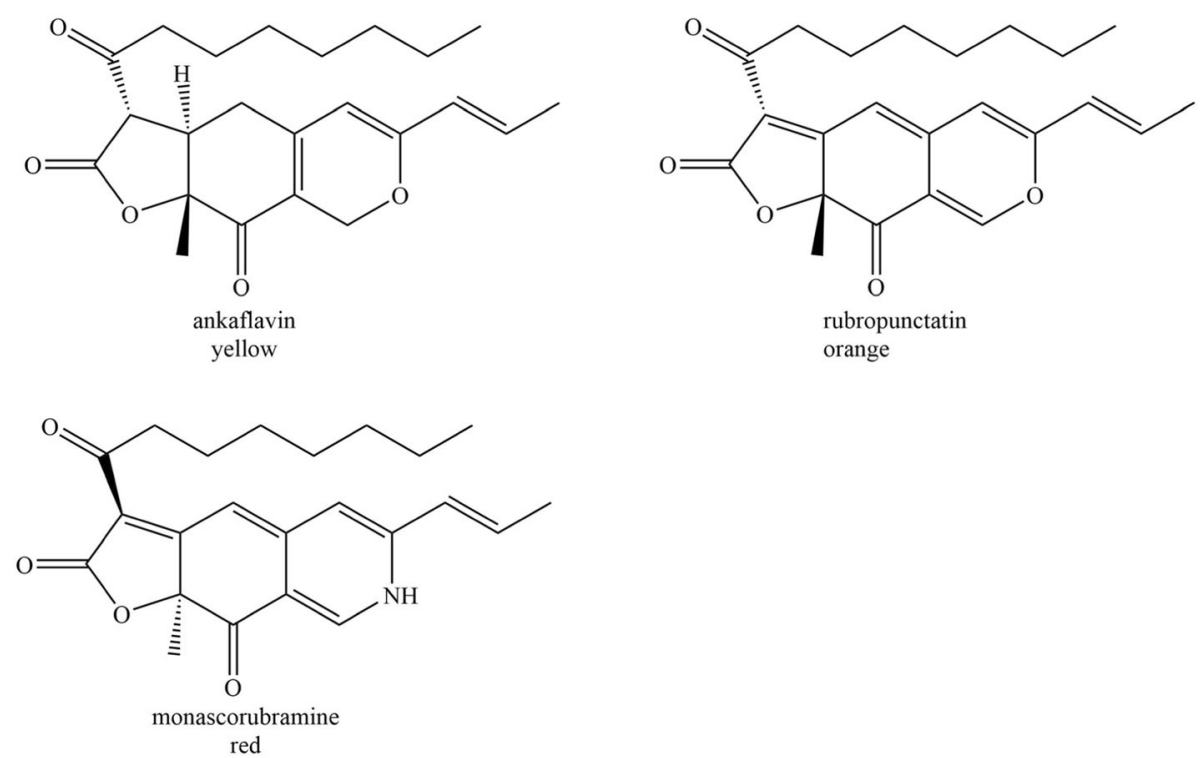

Fig. 3 Coloured substances from Monascus spp.

function as leather dyes but are not sufficiently effective to be commercially viable. Nevertheless, there is the potential of a new chemistry to be exploited (Fig. 3).

The production of synthetic dyestuffs is always ongoing: the options for creating and modifying new chemicals remain numerous, so a constant stream of new products is to be expected. However, it is interesting to see where new colourants are being found and to speculate where this takes the concept of sustainability in the colouring of leather and other materials.

\section{Fatliquoring}

The leather literature of the last decade contains little in the way of developments in lubrication technology. What is new is the advanced analytical approach to understanding the relationship between treatment and the impact on the physical status of collagen at the lowest level of fibre structure. Whilst the technology of fatliquoring is well known, it is less clear how that translates into mechanisms operating at the molecular level.

What is clear is that the fatliquoring is not simply a matter of lubricating the moving part of the collagen structure, to allow slippage. Lubricant can be shown to relax the fibrillar structure, as indicated by an extension of the D-period from 60.2 to $63.6 \mathrm{~nm}$, with the effect proportional to the lubricant offer [53]. The effect of fatliquor on collagen under strain has been investigated by small angle X-ray scattering: the organisation of the fibrillary structure increased and the extensibility increased [54].

The relationships between process reagents which modify the properties and performance of collagen and the changes made at the molecular level constitute a new approach to the materials science of leather. This is important work in the development of new modern collagenic biomaterials.

\section{Reagent delivery}

Tanning involves fixing reagents onto the collagenous substrate, traditionally using aqueous medium. This creates a problem for efficiency of reaction, because there is

Table 1 Melting points of some ionic compounds

\begin{tabular}{|l|c|c|}
\hline Cation & Anion & m.pt. ( $\left.{ }^{\circ} \mathbf{C}\right)$ \\
\hline $\mathrm{Ca}^{+}$ & $\mathrm{Cl}^{-}$ & 801 \\
\hline $\mathrm{Cl}^{+}$ & 772 \\
\hline & $\mathrm{Cl}^{-}$ & 87 \\
\hline & $\mathrm{Cl}^{-}$ & 65 \\
\hline & $\mathrm{NO}_{3}^{-}$ & 38 \\
\hline & $\mathrm{AlCl}^{-}$ & 7 \\
\hline & & \\
\hline
\end{tabular}




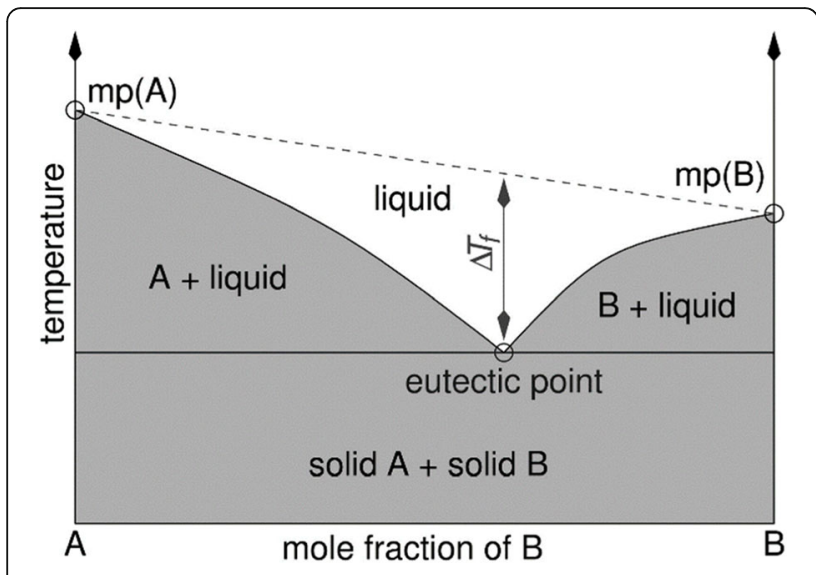

Fig. 4 The formation of a deep eutectic

typically competition between the substrate (the leather) and the solvent, when the reagent is partitioned between the two environments, dependent on the relative affinities of the reactivities. Other solvents for processing are well known: organic liquids, acetone, alcohol and chlorinated hydrocarbons were earliest examples, with paraffin, supercritical carbon dioxide and dimethyl ether more recent suggestions. In all these cases, the reduced affinity of the solvent for the substrate, typically basic chromium (III) salts, makes the substrates more attractive to the reagent and hence reaction is accelerated. However, each solvent has associated drawbacks, often flammability, toxicity or the need for pressure vessels.
Merely reducing the volume of water in processing, increasing the concentration of the reagent, can have a positive effect on the reaction efficiency, but here too there are associated problems: inertia in the drum, abrasion of the substrate and concentrated residues affect the practicability of such technologies. A useful option here is to replace the medium with plastic beads, a technology transferred from the laundry sector $[55,56]$. The contribution of the beads to movement and distribution of reagents makes this approach practical on the industrial scale.

A more radical approach is to employ a very different sort of solvent; an ionic liquid. This class of liquid depends on ions which form a lattice with weak bonds, dependent on the structures of the ions, as illustrated in Table 1 [57].

Some studies have been published introducing the concept to leather processing, with varying degrees of success [58]. Using ILs as a reagent in aqueous solution is not strictly changing the solvent, but benefits in terms of opening up have been reported [59].

An alternative approach is a variation on ionic liquids, in which a two component ionic mixture forms a deep eutectic, with a melting point lower than $100^{\circ} \mathrm{C}$, illustrated in Fig. 4 [60]. Understandably, for these systems to be used in the leather industry, it is of most use if the resulting melting point is below room temperature (Fig. 4).

This has been demonstrated as a useful option for both chrome and vegetable tanning [61, 62]. However, the more exciting aspect is the possibility of using

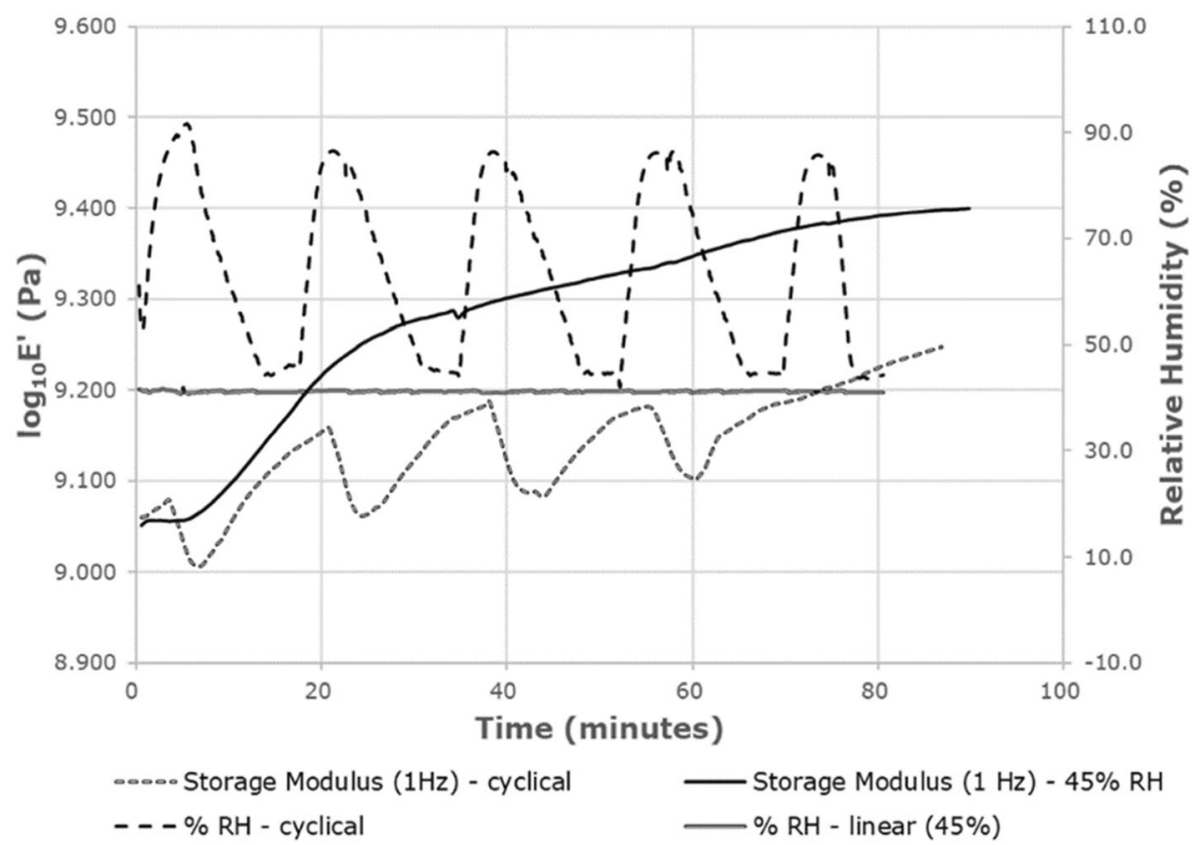

Fig. 5 The effect of pulses of moisture on wet organic tanned leather: viscoelastic response determined by dynamic mechanical thermal analysis (DMTA) 
chemistries currently not possible, for example introducing graphite deep into the collagen structure.

Novel reagent delivery is arguably the most important development in modern leather processing. Rethinking the way in which reagents are offered to collagen opens up the possibility for new chemistries to be developed to create new collagenic biomaterials.

\section{Drying}

There are complicated relationships between temperature, moisture content and the properties and performance of collagenic materials: this is illustrated in Fig. 5, showing the response of leather to pulses of humidity [63].

Figure 5 indicates the future of drying systems which can be tailored to impose leather properties, particularly softness and area yield $[64,65]$. In terms of the economics of leather production, this final step before finishing is arguably the most important and probably the least explored in leather science.

\section{Finishing}

The technology of finishing is still dominated by basecoat + topcoat, where the properties are defined by the chemistries of the layers, the intercoat adhesion and the leather to basecoat fixation. The chemistries employed are urethanes, acrylates, nitrocellulose and proteins: variations are usually in the precise chemical species, exemplified in Fig. 6 for acrylic compounds [66, 67].

Protein finishes are traditional, best known in the technology of glazing casein. Some researchers have demonstrated the possibility of using waste collagen, usually from wet blue by-products: this appears to be viable, but has yet to be applied commercially routinely $[68,69]$.

Finishing has not undergone radical change since the replacement of solvent for water-based formulations. This is an area for research with respect to the recyclability of leather at the end of life.

\section{Overview}

The sustainability of the global leather industry is constantly questioned, not least concerning its carbon and<smiles>C=CC(=O)OC(Cl)(Cl)Cl</smiles><smiles>C=CC(=O)OC</smiles><smiles>C=CC(=O)OCC</smiles><smiles>C=COCCCl</smiles>

2-chloroethyl vinyl (normally only a copolymer)<smiles>C=C(C)C(=O)OCCO</smiles>

2-hydroxyethyl methacrylate<smiles>C=C(C)C(=O)OCCCC</smiles>

butyl methacrylate<smiles>C=CC(=O)OCC(CC)CCCC</smiles>

2-ethylhexyl acrylate<smiles>C=CC(=O)OCCCC</smiles>

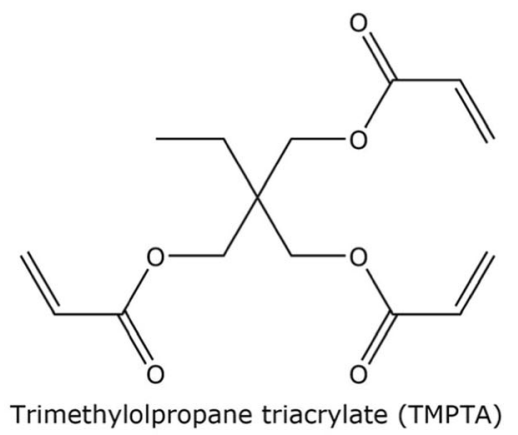

Fig. 6 Derivatives of acrylic acid 
water footprints. Brugnoli has addressed the issue, where some analysts have assigned large penalties to these two parameters on the basis that leather is a co-product with meat and consequently shares the burden of animal husbandry: his assertion is that leather is a by-product of the meat industry, so the calculation should start in the abattoir [70].

At the same time, attacks are being made on the modern global leather industry, labelling it dangerously polluting: for example by the Blacksmith Institute [71]. Here, the sector can defend itself, as in the robust response by Money [72]. Modern technologies of comprehensive recycling [17], waste treatment [73], innovation in reagent delivery $[74,75]$ and end of life [76] are testament to the commitment to environmentally sound operations.

In parallel developments, the creation of collagenic biomaterials de novo from sources other than intact animal skin is being actively researched. Modern Meadow [77] and the European project 'Diagenesis' [78] are examples. Such efforts are not in competition with the leather industry, since they cannot make leather by definition, but they can make analogous materials with different properties and performance.

\section{Acknowledgements}

The authors thank the Royal Society of Chemistry and Rachel Garwood, Director of ICLT, University of Northampton.

\section{Authors' contributions}

The authors are equally responsible for this publication. The author(s) read and approved the final manuscript.

\section{Funding}

University of Northampton, UK.

\section{Availability of data and materials}

Not applicable.

Ethics approval and consent to participate

Not applicable.

\section{Consent for publication \\ Not Applicable.}

\section{Competing interests}

The authors declare that they have no competing interests.

Received: 5 July 2020 Accepted: 2 October 2020

Published online: 15 December 2020

\footnotetext{
References

1. Tanning chemistry. The science of leather. 2nd edn. AD Covington, WR Wise (eds.) Royal Society of Chemistry: Cambridge, 2020. Print ISBN: 978-178801-204-1. EPUB ISBN: 978-1-78801-907-1.

2. Rao R, et al. J Amer Leather Chem Assoc. 2009;104(1):25.

3. Hashem MA, et al. J Amer Leather Chem Assoc. 2014;109(8):270.

4. Kanagaraj J, et al. J Soc Leather Technol Chem. 2015;99(3):107.

5. Rao R, et al. J Amer Leather Chem Assoc. 2010;105(11):360.

6. Aldema-Ramos ML, et al. J Amer Leather Chem Assoc. 2015;110(8):109.

7. Valeika V, et al. J Soc Leather Technol Chem. 2013;97(3):101.

8. Chandra Babu NK, et al. J Soc Leather Technol Chem. 2012;96(2):71.

9. Handbook of chemistry and physics. 95th edn., CRC Press: Boca Raton; 2014.

10. May PM, et al. Chem Commun. 2018;54:1980.
}

11. WR Wise et al. XXXV IULTCS Congress Dresden 2019 - full proceedings, 2019, Keynote, 53

12. Valeika V, et al. J Soc Leather Technol Chem. 2015;99(5):223.

13. ibid. 2015;99(5):231.

14. Song J, et al. J Soc Leather Technol Chem. 2015;99(3):115.

15. Rabinovich D. J Amer Leather Chem Assoc. 2011;106(8):242.

16. Fathima NN, et al. J Amer Leather Chem Assoc. 2016;111(6):206.

17. Daniels RP, et al. J Soc Leather Technol Chem. 2017;101(3):105.

18. Zhang W, et al. J Amer Leather Chem Assoc. 2016;111(3):101.

19. Moretto A. Regul Toxical Pharmacol. 2015;73:681.

20. Tegtmeyer D, Kleban M. IULTCS, IUR-1; 2013.

21. Zhang L, et al. J Soc Leather Technol Chem. 2010;94(4):156.

22. Ozgunay H, et al. J Soc Leather Technol Chem. 2015;99(5):245.

23. Ogata K, et al. J Soc Leather Technol Chem. 2018;102(2):53.

24. WR Wise. World leather: https://leatherbiz.com/fullitem.aspx?id=152851.

25. WR Wise. International leather manufacturer: https:// internationalleathermaker.com/news/fullstory.php/aid/7561/An_update_on_ chromium VI in_leather_methodology.html.

26. Bacardit A, et al. J Amer Leather Chem Assoc. 2014;109(4):117.

27. Chen D, et al. J Soc Leather Technol Chem. 2013;97(3):116.

28. Shi B, et al. J Amer Leather Chem Assoc. 2015;110(4):114.

29. Chen H, et al. J Amer Leather Chem Assoc. 2013;108(7):257.

30. Cheng H, et al. J Amer Leather Chem Assoc. 2013;108(11):428.

31. Cheng B, et al. J Soc Leather Technol Chem. 2015;99(3):120.

32. Shan Z, Liang Z, et al. J Soc Leather Technol Chem. 2012;96(5):210.

33. Sannino D, et al. J Soc Leather Technol Chem. 2013;97(4):139.

34. Kanth SV, et al. J Amer Leather Chem Assoc. 2010;105(1):16.

35. Kanth SV, et al. J Amer Leather Chem Assoc. 2009;104(11):405.

36. Morera JM, et al. J Amer Leather Chem Assoc. 2010;105(11):369.

37. S Jatay, YM Yoshi. via https://arxiv.org/pdf/1407-1462, Accessed 8 May 18.

38. Wei L, et al. J Soc Leather Technol Chem. 2016;100(1):25.

39. Suparno O, et al. J Soc Leather Technol Chem. 2009;93(4):158.

40. Suparno O, et al. J Amer Leather Chem Assoc. 2011;106(12):360.

41. Suparno O, et al. J Amer Leather Chem Assoc. 2013;108(5):180.

42. Vederaman N, et al. J Amer Leather Chem Assoc. 2015;110(7):221.

43. Zhou H, et al. J Soc Leather Technol Chem. 2011;95(6):250.

44. Bacardit, et al. J Soc Leather Technol Chem. 2011;95(6):259.

45. Ibid. 2012; 96(2):64.

46. Shi B, et al. J Soc Leather Technol Chem. 2014;98(1):17.

47. Sugiyama R, Chonan Y, Okamura H. Hikaku Kagaku. 1997;43(1):55.

48. Nair BU, et al. J Amer Leather Chem Assoc. 2011;106(2):50.

49. Clariant Int. Ltd., PCT/EP2010/001334, 2010.

50. Traubel H. J Amer Leather Chem Assoc. 2005;100(7):304.

51. Christie RM. Colour chemistry. CambridgeUK: RSC Publishing; 2015.

52. Fuck WF, et al. J Soc Leather Technol Chem. 2018;102(2):69.

53. Haverkamp RG, et al. J Amer Leather Chem Assoc. 2015;110(3):66.

54. ibid. 2015;110(11):355.

55. JE Steele. WO 2014/167358; 2014

56. S Rostami, J Steele, AD Covington. Proc., Asian International Conference on Leather Science and Technology, Okayama Japan, 2014.

57. WR Wise, AP Abbott, J Guthrie-Strachan. WO 2015/159070; 2015.

58. Mehta A, Raghava Rao J, Nishad Fathima N. J Phys Chem B. 2015;1 19:12816.

59. Nishad Fathima N, et al. RSC Adv. 2015;5:31998.

60. Smith EL, Abbott AP, Ryder KS. Chem Rev. 2014;114(21):11060.

61. Abbott A, Antunes APM, Covington AD, Mmapatsi B, Wise WR. Leather Int. 2016;217(4860):26.

62. Abbott AP, Alaysuy O, Antunes APM, Douglas AC, Guthrie-Strachan J, Wise WR. ACS Sustain Chem Eng. 2015;3:1241.

63. WR Wise, KB Flowers. unpublished results.

64. Wise WR, Covington AD, Flowers KB, Peruzzi A. J Amer Leather Chem Assoc. 2016;111(1):24.

65. Flowers KB, Peruzzi A, Wise WR, Covington AD. J Amer Leather Chem Assoc. 2015;110(10):317.

66. Yu Y, et al. Ind Eng Chem Res. 2014;53(2):564

67. Yoo Y, et al. J Appl Polym Sci. 2009;112:1587.

68. Zarlok J, et al. J Soc Leather Technol Chem. 2015;99(6):297.

69. Chunhui Z, Lu Q. J Soc Leather Technol Chem. 2014;98(6):269.

70. F Brugnoli. UNIDO, leather and leather products industry panel. Shanghai, 2012.

71. Blacksmith Institute. Pure earth. 2011. www.blacksmithinstitute.org.

72. Money CA. Leather Int. 2012. 
73. Haverkamp RG, et al. Sustainable Chem Eng. 2014;2(7):1864

74. A Abbott et al. Proc., SLTC Conf. 2014; Northampton.

75. A Abbott et al. UK Patent Appl. PCT/GB2014/051148, 2014.

76. A Duki. PhD thesis, University of Northampton, 2014.

77. A Forgacs. Modern Meadow, YouTube 2013.

78. P Netti. Lineapelle Innovation Square, 2018, Milan.

\section{Publisher's Note}

Springer Nature remains neutral with regard to jurisdictional claims in published maps and institutional affiliations.

Submit your manuscript to a SpringerOpen ${ }^{\circ}$ journal and benefit from:

- Convenient online submission

- Rigorous peer review

- Open access: articles freely available online

- High visibility within the field

- Retaining the copyright to your article

Submit your next manuscript at $\boldsymbol{\nabla}$ springeropen.com 